Original Research Paper

\title{
Effects of Extended-Rotifers Inclusion and Live Food- Enrichment with Probiotics on the Survival, Metamorphosis, Development Time and Growth of Mud Crab, Scylla paramamosain (Estampador) Larvae
}

\author{
${ }^{1,2}$ Quy Moc Ong, ${ }^{1}$ Ravi Fotedar and ${ }^{2}$ Thy Thi Truong Ho \\ ${ }^{1}$ School of Molecular and Life Science, Curtin University, \\ Kent Street, Bentley, Perth, Western Australia 6102, Australia \\ ${ }^{2}$ Department of Aquaculture, Faculty of Fisheries, Nong Lam University, \\ Linh Trung Ward, Thu Duc District, Ho Chi Minh City, Vietnam
}

\section{Article history}

Received: 01-06-2018

Revised: 11-06-2018

Accepted: 22-09-2018

Corresponding Author: Quy Moc Ong

School of Molecular and Life

Science, Curtin University,

Kent Street, Bentley, Perth,

Western Australia 6102,

Australia

Email: mocquyts@yahoo.com.vn

mocquy.ong@student.curtin.edu.au

\begin{abstract}
The present larval nutrition study was conducted to evaluate the effects of feeding probiotic-enriched rotifers inclusion mixed with Artemia until zoeal stages 4 (Z4) and Z5 on the survival, metamorphosis, development time and growth of mud crabs, Scylla paramamosain larvae. The efficiency of the feeding regime was tested by two-factor analysis. A $4 \times 2$ factorial experimental design with eight combinations of enriched or un-enriched or a mixture of enriched and un-enriched live food (factor 1) in each of two feeding regimes (factor 2) in triplicate was setup. After 24 days of larval cultivation, there were no significant $(p>0.05)$ interactive effects between the two selected factors on survival and metamorphosis rate of larvae. Larval survival in all treatments, under both factors, decreased gradually $(p<0.05)$ during the cultivation period. From 15 Days After Hatching (DAH), the survival and metamorphosis rates of larvae fed both enriched rotifers and Artemia were higher $(p<0.05)$ than those of the larvae without enriched live food. Similarly, from 18 DAH onwards, the extension of rotifers inclusion mixed with Artemia until Z5, irrespective of enrichment, showed higher $(p<0.05)$ survival, metamorphosis and growth of megalopa than when the rotifers were included only until Z4 stage. Overall, an amalgamation of extending rotifer feeding and enriching them at the same time with Artemia can result in considerable improvements in survival and metamorphosis which can in turn, have beneficial impact on the technical feasibility of a commercial crab hatchery.
\end{abstract}

Keywords: Mud Crab, Scylla paramamosain, Hatchery, Artemia, RotifersExtension, Probiotics

\section{Introduction}

Mud crab, Scylla paramamosain, is a commercially important source of income for coastal fishers in the Asia-Pacific region (Keenan, 1999). In Vietnam, $S$. paramamosain is the most prevalent cultured species in coastal areas (Le Vay et al., 2001; Lindner, 2005) and the second most common crustacean species after the shrimp (Penaeus monodon and Litopenaeus vannamei) (Nghia et al., 2007). The pond-based crab culture system totally relies on wild-caught seed (Keenan, 1999), which has become limited by over-exploitation and diminishing mangrove habitats (Le Vay et al., 2001). Although mud crab seed production has been studied extensively (Brick, 1974; Heasman and Fielder, 1983; Marichamy, 1996; Quinitio et al., 1999; Mann et al., 1999; Davis, 2003; Nghia et al., 2007; Yi et al., 2009; Noorbaiduri and Ikhwanuddin, 2015), the survival of hatchery-produced crablets is still unreliable and inconsistent (Baylon and Failaman, 1999; Hamasaki et al., 2011), mainly due to mass mortality during the zoeal $(Z)$ and megalopa stages, especially during metamorphosis from $\mathrm{Z} 5$ to megalopa (Hamasaki et al., 2002). Mass mortalities are mainly linked to poor larval nutrition (Hamasaki et al., 2002; 
Suprayudi et al., 2004) caused by selection of improper feeding regimes.

Nutritional deficiencies and inappropriate feeding regime, for example, feeding either rotifers alone (Nghia, 2004; Baylon, 2009), or exclusively Artemia (Ruscoe et al., 2004; Zeng et al., 2004), or excessive or starved Artemia (Suprayudi et al., 2002; Dan et al., 2016) to mud crab larvae resulted in low survival and prolonged larval development time. On the contrary, Artemia enriched with lecithin and cholesterol (Holme et al., 2007) as well as feeding a mixture of rotifers and Artemia to crab larvae (Zeng and Li, 1999; Nghia, 2004; Ruscoe et al., 2004) improves survival. Zeng and Li (1999), Ruscoe et al. (2004) and Nghia (2004) have recommended that the inclusion of rotifers should be extended until Z2 or Z3 stages to increase the survival of crab larvae. Similarly, our previous study (Quy et al., 2018) showed that including rotifers until the late zoeal stages ( $Z 3$ to $\mathrm{Z5}$ ), mixed with Artemia, increased in a higher metamorphosis of megalopa, thus, confirming that including the extension of rotifers in the feeding regime of mud crab larvae can contribute additional nutrients essential for moulting of most of the larval stages, as Artemia alone are incapable of providing these additional nutrients to the larvae (Baylon, 2009).

Similar to larval mal-nutrition, fungal, parasites and bacterial infections contribute to poor survival; however, enriching live feeds with probiotics increases survival rates (Dan and Hamasaki, 2015). Probiotics are defined as bio-friendly agents that can control and compete with pathogenic bacteria as well as stimulate the growth of aquatic animals without undesirable side effects (Farzanfar, 2006). The beneficial effects of dietary inclusion of probiotics are displayed through competition for habitat and nutrients to displace harmful bacteria (Moriarty, 1998), provision of nutrients and enhanced digestive enzyme activities (Ziaei-Nejad et al., 2006; Wang, 2007; Zhou et al., 2009; Gupta et al., 2016), improvement of water quality (Nimrat et al., 2012), enhancing immune responses (Rengpipat et al., 2000; Tseng et al., 2009; Kumar et al., 2013; Ambas, 2015) and producing antiviral substances (Lakshmi et al., 2013; Pandiyan et al., 2013). Although the beneficial uses of probiotics, including bacteria of the genus Bacillus, have been made in larval, post-larval and juvenile stages of shrimp (Rengpipat et al., 1998; Ziaei-Nejad et al., 2006; Balcázar and Rojas-Luna, 2007; Yu et al., 2008; Guo et al., 2009; Liu et al., 2010; Nimrat et al., 2012; Vinoj et al., 2013; Dong et al., 2014; Jamali et al., 2015) and in mud crab larvae and juvenile (Wu et al., 2014; Dan and Hamasaki, 2015; Talib et al., 2017), no information is available on the effects of supplementing probiotics and extending the inclusion of rotifers on the survival, metamorphosis, development time and growth of mud crab larvae. Thus, the aim of this study was to evaluate the effects of enriching live feeds (Artemia and rotifers) with commercially available Bacillus spp. as probiotics and extending the inclusion of rotifers until late zoeal stages of $S$. paramamosain.

\section{Materials and Methods}

\section{Water Source}

Seawater was pumped from the river and left one night in a reservoir tank before being disinfected with calcium hypochlorite at the rate of $20 \mathrm{mg} \mathrm{L}^{-1}$. After two day of chlorination, when no chlorine residue detected, the disinfected seawater was transferred into a storage tank, where the water was treated again with $2 \mathrm{mg} \mathrm{L}^{-1}$ Vikor-S (Bayer, Germany) for further use in the experiment.

\section{Live Food Culture}

According to the method described by Lind (2014), L-strain rotifers (Brachionus plicatilis) originated from a marine fish hatchery were stocked into indoor 4,000-L square concrete tank. The tank was filled $60 \%$ of disinfected seawater (30\%) and provided gently aeration by air-stone. Rotifers were fed a mixture diet of commercially available rotifer feed (S. parkle, INVE Aquaculture, Thailand) and baker's yeast $(50: 50)$ at a rate of $0.4 \mathrm{~g}$ for one million rotifers as recommended by Lind (2014) at $6 \mathrm{am}, 12 \mathrm{pm}$ and 6 pm daily. When density of rotifers achieved approximately 500 individuals $\mathrm{mL}^{-1}$, they were partially harvested to feed to mud crab larvae.

Artemia franciscana cysts were incubated by an incubation container. Before incubating, the cyst were disinfected with sodium hypochlorite solution at a concentration of $20 \mathrm{mg} \mathrm{L}^{-1}$ for $10 \mathrm{~min}$ to avoid any infection of harmful bacteria and fungi and then washed with seawater. Salinity and $\mathrm{pH}$ of disinfected seawater using for Artemia incubation were 30\%o and 8.3 , respectively. Strong aeration and light were also require. At the temperature of $29^{\circ} \mathrm{C}$, the newly hatched Artemia nauplii appeared after $15 \mathrm{~h}$ of incubation and they were harvested to enrich or directly feed to mud crab larvae.

\section{Method of Enriching the Live Foods}

Bacillus spp. is known as an effective probiotic bacteria in shrimp culture (Ambas et al., 2013), so a commercial probiotic (Lymnozyme FT-2B, Cisbay, USA) including Bacillus subtilis, B. licheniformis, $B$. amyloliquefaciens and B. Pumilus was used to enrich rotifers and Artemia in the current study. The rotifers, partially harvested from mass production in the 4,000-L square concrete tank, were washed with fresh seawater and stocked in a $10-\mathrm{L}$ plastic bucket containing $50 \%$ 
volume of disinfected seawater with gentle aeration. Probiotics and S. parkle at a rate of $1 \mathrm{mg} \mathrm{g}^{-1}$ of rotifer feed were placed together into a blender (HR2195/00, Philips, China) and blended with $100 \mathrm{~mL}$ of deionized water. This blended mixture was then poured into the bucket containing rotifers. The feeding rate of this mixture was adjusted following the rotifer stocking densities in the rearing medium which was $0.4 \mathrm{~g}$ of rotifer commercial feed meant to feed one million rotifers (for rotifer density of 1,000-1,500 rotifers $\left.\mathrm{mL}^{-1}\right)$. This was equivalently to $40 \mathrm{~mL}$ of the mixture of probiotics and rotifer commercial feed. This dose was based on the recommendation of feed company. After 6 hours of enrichment, rotifers were harvested and fed to crab larvae.

In contrast, newly hatched Artemia were only soaked in the commercial probiotic suspension and disinfected seawater at a rate of $1 \mathrm{mg} \mathrm{L}^{-1}$, with strong aeration. This enrichment process lasted only for $1 \mathrm{~h}$ in order to avoid nutrient losses in Artemia due to their quick assimilation efficiencies. The enrichment protocol was strictly followed and the supplemented weight of the probiotic powder was measured by an analytical balance (PA 214-Ohaus, USA) with 0.0001 $\mathrm{g}$ precision. The newly hatched Artemia (instar 1) is not fully developed and thus are unable to ingest the food from water, though, they can absorb water containing Bacillus. As a result, the Bacillus could be resident of both gut and the external body of Artemia. To verify the final concentration of the probiotics, homogenised sample taken from whole rotifers or Artemia was used to determine total Bacillus spp. on Tryptic Soy Agar (TSA) plates.Total Bacillus spp. concentration in enriched rotifers and Artemia were counted periodically and also at the end of the trial in plates containing TSA medium, according to the method described by Tomasiewicz et al. (1980).

\section{Mud Crab Brood Stock and Larval Source}

Mature and berried females of $S$. paramamosain were fattened and managed as described by Quy et al. (2018). During the fattening period, the salinity and water temperature ranged from 28 to $30 \%$ and 28 to $29^{\circ} \mathrm{C}$, respectively, while photoperiod was exposed to 12: 12 of light: Dark cycle following natural lights. One day before hatching, the berried female was transferred and individually reared in a $200-\mathrm{L}$ round tank for hatching.

Newly hatched Z1 larvae, from single spawners, were collected and bathed in $0.1 \mu \mathrm{L} \mathrm{L}^{-1}$ iodine solution for 30 seconds and they were then temporarily reared into a 100 -L plastic bucket. The larvae were fed purely with the rotifers without enrichment with probiotics at a rate of 40-50 individuals $\mathrm{mL}^{-1}$. On the next day, the larvae were used for the experiment.

\section{Experimental Design}

Based on our previous research (Quy et al., 2018), which aimed to extend the inclusion of rotifers into the feeding regime of mud crab larvae, two feeding regimes viz. extending rotifers inclusion mixed with Artemia until Z4 and Z5 stages, were selected. In the current study, rotifers and Artemia in these feeding regimes (extending rotifers until $\mathrm{Z} 4$ and $\mathrm{Z5}$ ) were enriched with a commercial probiotic. The enriched/un-enriched live food was defined as a first factor and extension of rotifers inclusion as a second factor. A $4 \times 2$ factorial experimental design with eight various combinations of enriched or un-enriched or a mixture of enriched and un-enriched live food (factor 1) in each of two feeding regimes (factor 2) in triplicate was tested (Table 1). Enriched or unenriched rotifers were fed from $Z 1$ crab larvae and extended until the next day of the moulting to $Z 4$ and Z5 stages, depending upon the selection of the extension of rotifers inclusion, whereas enriched or un-enriched Artemia nauplii were offered to these treatments from Z2 stage until the megalopa stage.

Twenty-four 1.5-L plastic beakers in which each beaker was filled with $1 \mathrm{~L}$ of disinfected seawater (30\%o) and stocked with 30 mud crab $\mathrm{Zl}$ collected from the $100-\mathrm{L}$ plastic bucket. The beakers were moderately aerated to prevent settlement of live food and larvae. All the experimental beakers were maintained at a constant temperature $\left(28 \pm 1^{\circ} \mathrm{C}\right)$ by immersing in a 5,000-L square concrete tank. To improve ability to catch the prey and possibly reduce any mortality by cannibalism or infection, the photoperiod was maintained constantly for $24 \mathrm{~h}$ by a $40-\mathrm{W}$ fluorescent lamp. The $\mathrm{pH}$ of disinfected seawater was balanced approximately to $8.3 \pm 0.2$ by adding $\mathrm{CaCO}_{3}$ and/or $\mathrm{NaHCO}_{3}$ before being distributed into every experimental beaker.

Table 1: Experimental feeding treatments (design) showing combinations of enriched/un-enriched live food and extension of rotifer inclusion for S. paramamosain larvae

\begin{tabular}{llll}
\hline & & Enrichment & \\
$\begin{array}{l}\text { Extension of } \\
\text { rotifer inclusion }\end{array}$ & $\begin{array}{l}\text { Un-enriched } \\
\text { Artemia } \text { and rotifers }\end{array}$ & $\begin{array}{l}\text { En-Rotifers } \\
\text { only }\end{array}$ & $\begin{array}{l}\text { En-Artemia } \\
\text { only }\end{array}$ \\
\hline Until zoea 4 stage & R \& A & En-R \& A & R \&En-A \\
Until zoea 5 stage & R \& A & En-R \& A & En-R \&En-A \\
\hline
\end{tabular}

R: Un-enriched rotifers; A: Un-enriched Artemia; En-R: Enriched rotifers; En-A: Enriched Artemia 
Mud crab larvae were fed only rotifers at a rate of 20 individuals (ind.) $\mathrm{mL}^{-1}$ from $\mathrm{Zl}$ to $\mathrm{Z} 2$ and then fed a mixture of rotifers and Artemia at a rate of 10 and 5 ind. $\mathrm{mL}^{-1}$, respectively, until $\mathrm{Z} 4$ and $\mathrm{Z5}$, depending upon the treatment in factor 2. After rotifers inclusion was stopped, the density of Artemia in the feeding regime was increased from 5 to 10 ind. $\mathrm{mL}^{-1}$ until the end of the experiment. The desired densities of rotifers and Artemia nauplii in every beaker was prepared following the method described by Baylon (2009). Feeding time was applied only once a day after all crab larvae were transferred into a newly prepared beaker. The newly beakers were filled with disinfected seawater of the same environmental parameters of the replaced beakers and the larvae were carefully and quickly transferred with the help of a large bore pipette. At the same time, larval metamorphosis and mortality was recorded in each beaker. When megalopa stage appeared, they were immediately moved out to avoid cannibalism. Ten megalopa were collected and preserved in $10 \%$ formalin solution for further measurements of carapace widths, body lengths and wet weights. The experiment was ended at 24 days after hatching. The survival of the larvae, consisting of zoea and megalopa was computed using the following equation:

$$
\text { Survival rate }=\frac{\text { Final larvae }}{30 \text { zoae } 1 \text { stocked }} \times 100
$$

Megalopa carapace width and body length were measured using a scale inserted into the eyepiece of a microscope (Olympus CX21, USA), then they were dried on tissue paper for wet weight. The wet weight of megalopa was weighted by an analytical balance (PA 214-Ohaus, USA) with $0.0001 \mathrm{~g}$ precision.

\section{Statistical Analysis}

All data in the treatments presented in percentages, such as survival of larvae and percentage of successfully metamorphosed megalopa, were arcsine-square root transformed (Zar, 2010) before analysis. Two-way ANOVA was used to test for significant differences among treatments. In the case of no significant interactive effects between enriched/un-enriched live food and extension of rotifers inclusion, two-way ANOVA was continuously employed to test for various enrichment/non-enrichment and two levels of extensions of rotifers inclusion. If there were significant interactive effects between enriched/un-enriched live food and extension of rotifers inclusion, one-way ANOVA was employed to test for various effects of enrichment/nonenrichment, extension of rotifers inclusion and interaction between enrichment/non-enrichment and extension of rotifers inclusion. Significant differences between the treatments were detected by Tukey's multiple range tests at the 0.05 level of significance. Kruskal-Wallis non-parametric tests was used to compare megalopa carapace width, body length and wet weight because of unequal sample size (amount of megalopa of some replicate in treatments were not enough); significant differences between the treatments were detected by Mann-Whitney Test at the 0.05 level of significance. All statistical analyses were performed using IBM SPSS Statistics 24.0.

\section{Results}

Environmental Parameters and Concentration of Total Bacillus spp. of Enriched Live Food

During the experiment, the salinity and $\mathrm{pH}$ in all experimental beakers were stable at $30 \%$ and 8.6, respectively. Alkalinity was constant at $140 \mathrm{mg} \mathrm{CaCO}_{3}$ $\mathrm{L}^{-1}$. While water temperature was $27.9 \pm 0.5^{\circ} \mathrm{C}$ throughout the experimental period.

After enriching live food, the total Bacillus spp. counted in enriched rotifers and Artemia were 2.0 \pm 0.70 $\left(\times 10^{6}\right) \mathrm{cfu} \mathrm{g}^{-1}$ and $3.3 \pm 0.07\left(\times 10^{6}\right) \mathrm{cfu} \mathrm{g}^{-1}$, respectively.

\section{Larval Survival}

There were no significant $(p>0.05)$ interactive effects between enriched/un-enriched live food with probiotics (factor 1) and extension of rotifers inclusion (factor 2) on mud crab larval survival; the main effect was examined independently for two factors (Table 2). Larval survival in all treatments (in both factors) decreased gradually $(p<0.05)$ during the culture period. The survival of larvae fed both enriched rotifers and Artemia was higher $(p<0.05)$ than that of larvae fed a diet without enrichment ( $R$ \& A) from 15 Days After Hatching (DAH) onwards and a diet enriched with rotifers only from 15 to $18 \mathrm{DAH}$. However, the larval survival at the end of the feeding experiment was not altered $(p>0.05)$ by enrichment when enrichment was carried out individually either to rotifers or Artemia. Similarly, extension of rotifers inclusion influenced $(p<0.05)$ the survival of larvae from $18 \mathrm{DAH}$ onwards, in which the larvae fed rotifers mixed with Artemia until Z5 showed significantly higher survival than those fed rotifers inclusion until Z4.

There was a negative correlation between larval survival and culture period (Table 3), with regression indices $\left(\mathrm{R}^{2}\right)$ ranging from 0.96 to 0.99 . These indices were, however, independent $(p>0.05)$ of enrichments and extension of rotifers inclusion in diets with Artemia.

\section{Rate of Metamorphosis and Development Time of Megalopa}

Mud crab larvae fed both enriched rotifers and Artemia (En-R \&En-A) showed a higher $(p<0.05)$ rate of metamorphosis of megalopa $(37.2 \%)$ than those fed a 
diet without enrichment $(\mathrm{R} \& \mathrm{~A})(12.8 \%)$ and a diet enriched with rotifers only (En-R \& A) (17.2\%). Similarly, the larvae fed rotifers inclusion mixed with Artemia until Z5 showed a significantly higher $(p<0.05)$ metamorphosis rates $(27.5 \%)$ than larvae fed rotifers inclusion until Z4 (15.8\%) (Fig. 1). Morphological variation was also less seen in the feeding treatments that had high successful metamorphosis of megalopa. However, the duration to metamorphose from $\mathrm{Z} 1$ to the megalopa stage (development time) did not completely depend $(p>0.05)$ on enrichments and feeding duration with rotifers (Fig. 2).

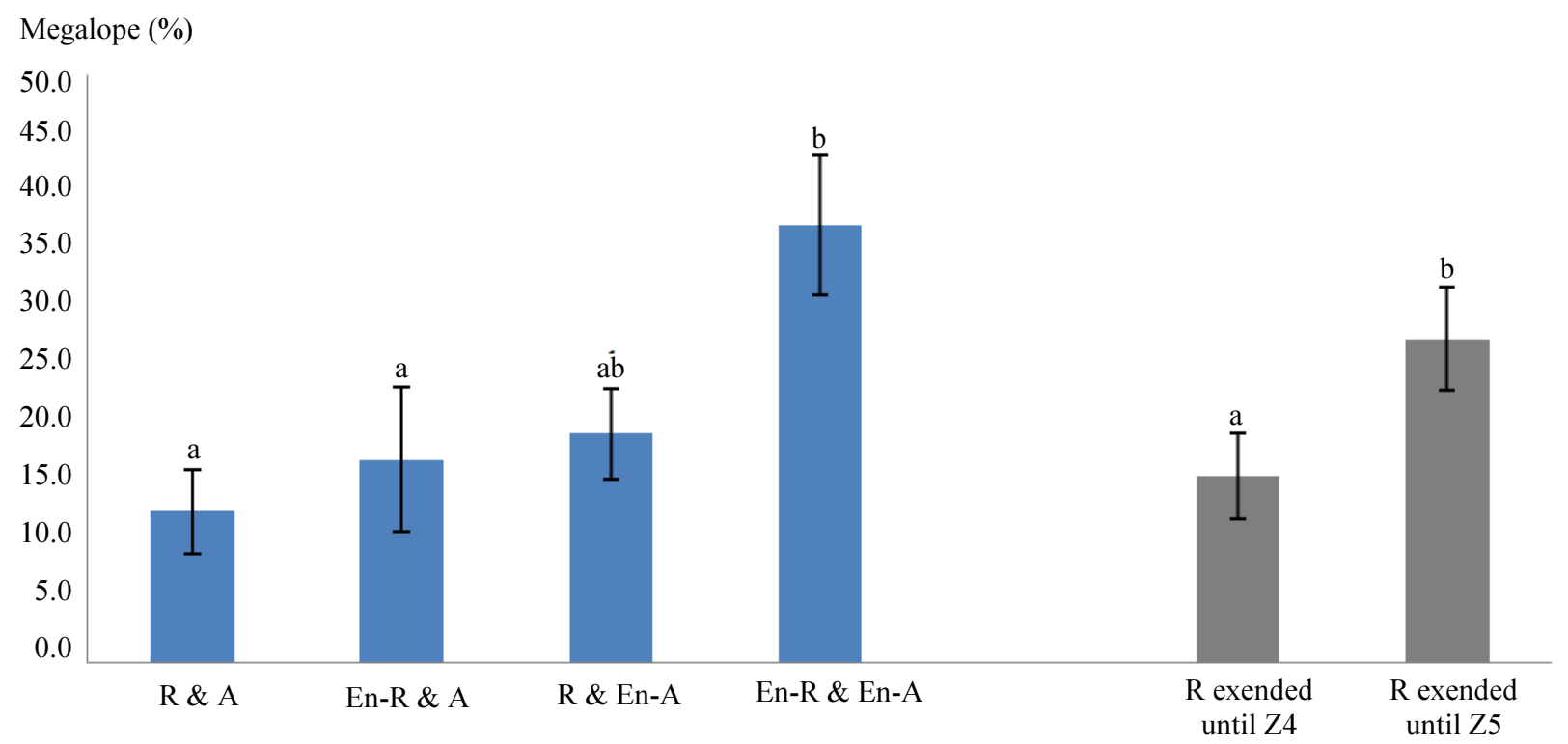

Fig. 1: Percentage of successful metamorphosis of megalopa fed according to different enrichments and extending rotifers inclusion mixed with Artemia. The bars, regardless to colours, present mean percentage of megalopa and error bars present \pm standard error $(n=3)$.R: Un-enriched rotifers; A: Un-enriched Artemia; En-R: Enriched rotifers; En-A: Enriched Artemia. Significant differences were found among all treatments with different superscript letters $(p<0.05)$ forbars with the same colour

Days

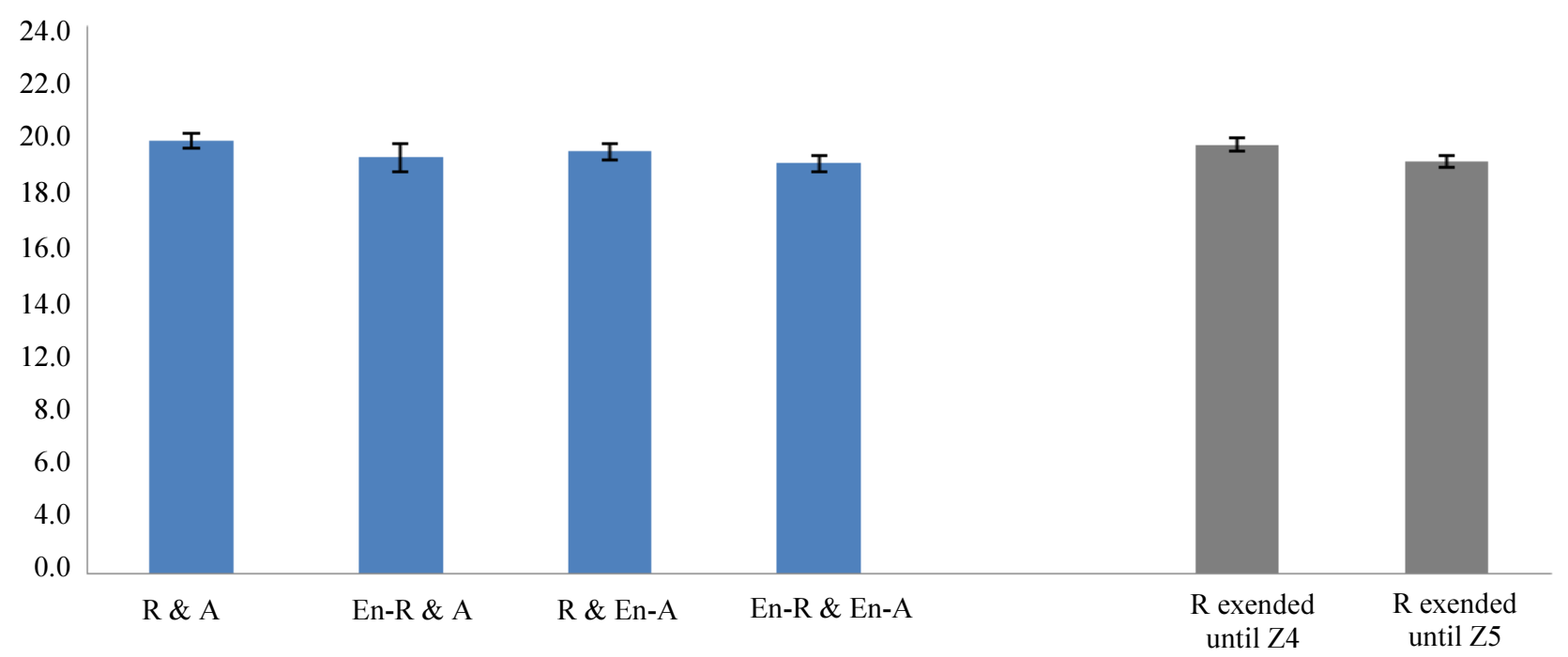

Fig. 2: Duration of rearing period needed for metamorphosis from zoea 1 to megalopa stage under various feeding regimes. The bars, regardless to colours, present mean development time of megalopa and error bars present \pm standard error $(n=3)$. R: Un-enriched rotifers; A: Un-enriched Artemia; En-R: Enriched rotifers; En-A: Enriched Artemia 
Table 2:Mean survival \pm Standard Error (SE) of crab larvae fed according to different enrichments and extending rotifer inclusion mixed with Artemia for 24 days of culture

\begin{tabular}{|c|c|c|c|c|c|c|}
\hline \multirow[b]{3}{*}{ Days } & \multicolumn{6}{|l|}{ Factors } \\
\hline & \multicolumn{4}{|c|}{ Enriched/un-enrichment live food } & \multicolumn{2}{|c|}{ Extension of rotifers } \\
\hline & $\mathrm{R} \& \mathrm{~A}$ & En-R \& A & $\mathrm{R} \& \mathrm{En}-\mathrm{A}$ & En-R \&En-A & Until Z4 & Until Z5 \\
\hline 3 & $95.0 \pm 1.67^{\mathrm{a}}$ & ${ }^{1} 93.3 \pm 2.11^{\mathrm{a}}$ & ${ }^{1} 96.7 \pm 1.49^{\mathrm{a}}$ & ${ }^{1} 97.2 \pm 0.56^{\mathrm{a}}$ & ${ }^{1} 96.9 \pm 0.76^{\mathrm{a}}$ & ${ }^{1} 94.2 \pm 1.31^{\mathrm{a}}$ \\
\hline 6 & ${ }^{2} 72.2 \pm 2.94^{\mathrm{a}}$ & ${ }^{12} 78.3 \pm 4.01^{\mathrm{a}}$ & ${ }^{2} 79.4 \pm 2.91^{\mathrm{a}}$ & ${ }^{12} 86.1 \pm 2.78^{a}$ & ${ }^{2} 79.7 \pm 2.61^{\mathrm{a}}$ & ${ }^{2} 78.3 \pm 2.61^{\mathrm{a}}$ \\
\hline 9 & ${ }^{23} 57.2 \pm 7.95^{\mathrm{a}}$ & ${ }^{23} 69.4 \pm 3.98^{\mathrm{a}}$ & ${ }^{23} 70.0 \pm 4.39^{\mathrm{a}}$ & ${ }^{23} 76.7 \pm 1.92^{\mathrm{a}}$ & ${ }^{23} 65.8 \pm 4.48^{\mathrm{a}}$ & ${ }^{23} 70.8 \pm 2.76^{\mathrm{a}}$ \\
\hline 12 & ${ }^{234} 45.0 \pm 9.26^{\mathrm{a}}$ & ${ }^{34} 48.3 \pm 7.33^{\mathrm{a}}$ & ${ }^{34} 57.8 \pm 6.48^{\mathrm{a}}$ & ${ }^{23} 71.1 \pm 3.51^{\mathrm{a}}$ & ${ }^{34} 51.1 \pm 6.03^{\mathrm{a}}$ & ${ }^{34} 60.0 \pm 4.91^{\mathrm{a}}$ \\
\hline 15 & ${ }^{345} 31.7 \pm 7.54^{\mathrm{a}}$ & ${ }^{45} 37.2 \pm 7.62^{\mathrm{a}}$ & ${ }^{4} 47.8 \pm 4.99^{\mathrm{ab}}$ & ${ }^{345} 61.7 \pm 4.77^{\mathrm{b}}$ & ${ }^{45} 38.9 \pm 5.32^{\mathrm{a}}$ & ${ }^{45} 50.3 \pm 5.15^{\mathrm{a}}$ \\
\hline 18 & ${ }^{45} 23.3 \pm 5.84^{\mathrm{a}}$ & ${ }^{45} 29.4 \pm 6.96^{\mathrm{a}}$ & ${ }^{45} 37.2 \pm 4.16^{\mathrm{ab}}$ & ${ }^{456} 54.4 \pm 5.62^{\mathrm{b}}$ & ${ }^{56} 30.0 \pm 4.85^{\mathrm{a}}$ & ${ }^{456} 42.2 \pm 4.93^{b}$ \\
\hline 21 & ${ }^{5} 16.1 \pm 4.67^{\mathrm{a}}$ & ${ }^{45} 22.2 \pm 6.19^{\mathrm{ab}}$ & ${ }^{5} 24.2 \pm 3.06^{\mathrm{ab}}$ & ${ }^{56} 40.6 \pm 6.74^{\mathrm{b}}$ & ${ }^{6} 20.0 \pm 3.74^{\mathrm{a}}$ & ${ }^{56} 31.7 \pm 4.56^{\mathrm{b}}$ \\
\hline 24 & ${ }^{5} 13.9 \pm 3.59^{\mathrm{a}}$ & ${ }^{5} 20.0 \pm 5.84^{\mathrm{ab}}$ & ${ }^{5} 21.7 \pm 3.19^{\mathrm{ab}}$ & ${ }^{6} 38.9 \pm 6.70^{\mathrm{b}}$ & ${ }^{6} 18.1 \pm 3.75^{\mathrm{a}}$ & ${ }^{6} 29.2 \pm 4.38^{\mathrm{b}}$ \\
\hline
\end{tabular}

R: Un-enriched rotifers; A: Un-enriched Artemia; En-R: Enriched rotifers; En-A: Enriched Artemia. Significant differences were found among all treatments with different superscript letters $(p<0.05)$ in the same row for each factor. Significant differences were also found throughout the cultivation period within each treatment with different superscript numbers $(p<0.05)$ in the same column

Table 3: Relationships between survival and day of culture of crab larvae fed with different enrichments and extension of rotifer inclusion mixed with Artemia

\begin{tabular}{llc}
\hline Treatment & Equation & Regression $\left(\mathrm{R}^{2}\right)$ \\
\hline R \& A & $\mathrm{y}=-3.91 \mathrm{x}+97.46$ & $0.96 \pm 0.02$ \\
En-R \& A & $\mathrm{y}=-3.69 \mathrm{x}+99.60$ & $0.97 \pm 0.01$ \\
R \&En-A & $\mathrm{y}=-3.54 \mathrm{x}+101.90$ & $0.99 \pm 0.01$ \\
En-R \&En-A & $\mathrm{y}=-2.74 \mathrm{x}+102.50$ & $0.99 \pm 0.00$ \\
R extended until zoae 4 & $\mathrm{y}=-3.81 \mathrm{x}+101.28$ & $0.98 \pm 0.01$ \\
R extended until zoae 5 & $\mathrm{y}=-3.13 \mathrm{x}+99.43$ & $0.99 \pm 0.01$ \\
\hline
\end{tabular}

R: Un-enriched rotifers; A: Un-enriched Artemia; En-R: Enriched rotifers; En-A: Enriched Artemia. Y represents the survival of larvae and $X$ the day of culture. Values are mean $\pm S E$.

Table 4: Mean carapace width, body length and wet weight of one-day-old megalopa fed according to different enrichments and extension of rotifers inclusion mixed with Artemia

Factors

Enriched/un-enriched live food

\begin{tabular}{lllllll} 
Parameters & R\&A & En-R\&A & R\&En-A & En-R\&En-A & Until Z4 & Until Z5 \\
\hline CW $(\mathrm{mm})$ & $1.63 \pm 0.01^{\mathrm{a}}$ & $1.64 \pm 0.01^{\mathrm{a}}$ & $1.63 \pm 0.02^{\mathrm{a}}$ & $1.66 \pm 0.01^{\mathrm{a}}$ & $1.62 \pm 0.01^{\mathrm{a}}$ & $1.66 \pm 0.01^{\mathrm{b}}$ \\
BL (mm) & $4.91 \pm 0.05^{\mathrm{a}}$ & $4.97 \pm 0.03^{\mathrm{a}}$ & $4.96 \pm 0.01^{\mathrm{a}}$ & $4.98 \pm 0.03^{\mathrm{a}}$ & $4.93 \pm 0.03^{\mathrm{a}}$ & $4.98 \pm 0.02^{\mathrm{a}}$ \\
WW (mg) & $3.84 \pm 0.11^{\mathrm{a}}$ & $3.90 \pm 0.12^{\mathrm{a}}$ & $3.92 \pm 0.12^{\mathrm{a}}$ & $3.94 \pm 0.07^{\mathrm{a}}$ & $3.77 \pm 0.07^{\mathrm{a}}$ & $4.02 \pm 0.05^{\mathrm{b}}$ \\
\hline
\end{tabular}

R: Un-enriched rotifers; A: Un-enriched Artemia; En-R: Enriched rotifers; En-A: Enriched Artemia; CW: Carapace width; BL: Body length; $W W$ : Wet weight. Values representmean \pm SE. Significant differences were found among all treatments with different superscript letters $(p<0.05)$ in the same row for each factor.

\section{Growth Performance of Megalopa}

Enrichment of live food did not significantly $(p>0.05)$ influence carapace width, body length and wet weight of megalopa, but extension of rotifers inclusion mixed with Artemia until Z5 improved $(p<0.05)$ carapace width and wet weight of megalopa $(1.66 \mathrm{~mm}$ and $4.02 \mathrm{mg}$, respectively) compared to the treatment in which rotifers were included until Z4 $(1.62 \mathrm{~mm}$ and 3.77 $\mathrm{mg}$, respectively; Table 4).

\section{Discussion}

Previous research has shown that Bacillus spp. can have significant effects on crustaceans (Table 5), mediated by improved water quality (Soundarapandian and Sankar,
2008; Nimrat et al., 2012), enhanced digestive enzyme activities (Ziaei-Nejad et al., 2006) and increased health status (Uddin et al., 2013) of the host. Likewise, a feeding regime including rotifers and Artemia improved the survival of mud crab larvae (Baylon and Failaman, 1999; Zeng and Li, 1999; Nghia, 2004; Ruscoe et al., 2004).

To our knowledge, this is the first study investigating the effects of extending rotifer feeding in an Artemia-based diet with enriched live foods, both Artemia and rotifers, with a commercial probiotic based on Bacillus spp. in mud crab (S. paramamosain) larvae. In the current study, a diet that included both enriched rotifers and Artemia with probiotics increased survival and metamorphosis rates of megalopa compared to a diet without enriched live food. The same results were obtained in $L$. vannamei fed both 
enriched rotifer and Artemia (Jamali et al., 2015). Total bacteria and probiotic Bacillus increased in the host (Jamali et al., 2015) that resulted in increasing activity of digestive enzymes (Ziaei-Nejad et al., 2005) and inhibiting the growth of pathogens (Decamp et al., 2008), which in turn improved larval survival. In addition, Nogami et al. (1997) reported that the bacterial strain PM4 (Thalassobacterutilis), which was added daily into rearing water increased the survival of swimming crab (Portunus trituberculatus) larvae by repressing the growth of harmful bacteria and fungi. Dan and Hamasaki (2015) also found that suppressing larval necrosis symptoms and improving survival of early larvae of $S$. serrata were done when probiotics was inoculated in the larval rearing water. Although the mode of probiotic administration differed between our study and the previously mentioned studies, the beneficial outcomes of probiotics were not significantly different (Ziaei-Nejad et al., 2005). Similar to the factorial 1 outcome, the inclusion of rotifers mixed with Artemia until Z5 improved megalopa survival, metamorphosis rate and growth compared to the treatment where rotifers were included only until Z4.

Previous studies have also shown that a mixed diet of rotifers and Artemia until the late zoeal stages improved larval survival of $S$ serrata (Baylon and Failaman, 1999), P. Pelagicus (Redzuari et al., 2012), Upogebia pusilla (Faleiro and Narciso, 2009) and Panopeus herbstii (Harvey and Epifanio, 1997), but these studies failed to mention the benefits that achieved as extending of rotifers inclusion. In the present study, morphological variation and formation of immature megalopa, resulting from accumulation of insufficient nutrients (Dan et al., 2013) were less seen in the crab larvae fed rotifers inclusion mixed with Artemia until Z5 than in those fed rotifers inclusion only until $\mathrm{Z} 4$. This could be due to the starvation of Artemia that can be reduced to a certain extent by feeding them rotifer excrements (Dan et al., 2016). Crab larvae can be exposed to less starved Artemia when rotifers are present until Z5 in a mixed diet with Artemia.

Additionally, morphological variation and formation of immature megalopa, which are caused by quantity of available food (Pestana and Ostrensky, 1995), may be less appearance as rotifers and Artemia, both are available in rearing water in our study. According to Genodepa et al. (2004), the feeding behaviour of mud crab larvae is raptorial. The late zoeal stages showed a strong preference for Artemia, which supplied the majority of energy intake required for moulting to the next stage (Harvey and Epifanio, 1997); however, after moulting, they preferred rotifers, which provided energy for survival (Baylon et al., 2004). This indicates that extending rotifers inclusion, mixed with Artemia, until Z5 can provide additional benefits in reducing the morphological variation and the formation of immature megalopa, which would result in mass mortality of crab larvae (Dan et al., 2013).

Table 5: Uses of probiotic Bacillus species in crustacean aquaculture

\begin{tabular}{|c|c|c|c|c|}
\hline Probiotic & Target host species & $\begin{array}{l}\text { Doses and } \\
\text { administration duration }\end{array}$ & Response & References \\
\hline $\begin{array}{l}\text { B. subtilis } \\
\text { UTM } 126\end{array}$ & Litopenaeus vannamei & $10^{5} \mathrm{cfu} \mathrm{g}^{-1}$ feed for 28 days & Resistance of Vibrio species & $\begin{array}{l}\text { Balcázar and Rojas-Luna } \\
(2007)\end{array}$ \\
\hline B. subtilis & Litopenaeus vannamei & $10^{10} \mathrm{cfu} \mathrm{g}^{-1}$ feed for 30 days & $\begin{array}{l}\text { Increased survival and yield } \\
\text { and reduced Vibrio }\end{array}$ & Far et al. (2009) \\
\hline B. subtilis & Litopenaeus vannamei & $10^{10} \mathrm{cfu} \mathrm{g}^{-1}$ feed for 20 days & Against white spot syndrome virus & Fu et al. (2011) \\
\hline B. subtilis- E20 & Litopenaeus vannamei & $10^{9} \mathrm{cfu} \mathrm{L}^{-1}$ for 14 days & $\begin{array}{l}\text { Increased survival and } \\
\text { immune response of larvae }\end{array}$ & Liu et al. (2010) \\
\hline B. subtilis- E20 & Litopenaeus vannamei & $10^{8} \mathrm{cfu} \mathrm{g}^{-1}$ feed for 98 days & $\begin{array}{l}\text { Increased survival and disease } \\
\text { resistance }\end{array}$ & Tseng et al. (2009) \\
\hline B. subtilis & Penaeus monodon & $10^{10} \mathrm{cfu} \mathrm{g}^{-1}$ feed for 90 days & Disease protection & Rengpipat et al. (2000) \\
\hline B. $S 11$ & Penaeus monodon & $0.4 \mathrm{mg} \mathrm{g}^{-1}$ feed for 90 days & Increased growth and immunity & $\begin{array}{l}\text { NavinChandran et al. } \\
\text { (2014) }\end{array}$ \\
\hline B. cereus & Macrobrachium rosenbergii & $10^{9} \mathrm{cfu}^{-1}$ diet for 60 days & $\begin{array}{l}\text { Increased survival, growth, feed } \\
\text { use, digestive enzyme activity } \\
\text { and innate immune response }\end{array}$ & Gupta et al. (2016) \\
\hline B. coagulans & Macrobrachium rosenbergii & $10^{9} \mathrm{cfu} \mathrm{g}^{-1}$ diet for 60 days & $\begin{array}{l}\text { Increased growth, feed use and } \\
\text { immune parameters }\end{array}$ & Kumar et al. (2013) \\
\hline B. licheniformis & Marsupanaeus japonicas & $10^{8} \mathrm{cfu} \mathrm{g}^{-1}$ diet for 60 days & $\begin{array}{l}\text { Increased survival, growth and } \\
\text { immune response and reduced } \\
\text { Vibrio }\end{array}$ & Dong et al. (2014) \\
\hline Bacillus spp. & Litopenaeus vannamei & $10^{5} \mathrm{cfu} \mathrm{mL} \mathrm{m}^{-1}$ & $\begin{array}{l}\text { Increased survival and } \\
\text { resistance of Vibrio species }\end{array}$ & $\begin{array}{l}\text { Luis-Villaseñor et al. } \\
\text { (2011) }\end{array}$ \\
\hline Bacillus spp. & Litopenaeus vannamei & $10^{9} \mathrm{cfu} \mathrm{g}^{-1}$ diet for 60 days & $\begin{array}{l}\text { Improved growth and survival } \\
\text { of larvae }\end{array}$ & Nimrat et al. (2012) \\
\hline Bacillus spp. & Fenneropenaeus indicus & $10^{6}$ cfu mL $\mathrm{m}^{-1}$ & $\begin{array}{l}\text { Improved growth, survival and } \\
\text { digestive enzyme activity of larvae }\end{array}$ & $\begin{array}{l}\text { Ziaei-Nejad et al. } \\
(2006)\end{array}$ \\
\hline
\end{tabular}


For cost-effective aspect, Ruscoe et al. (2004) and Baylon (2009) found that extending rotifers inclusion until late zoeal stages with Artemia does not provide economic benefits due to the use of expensive resources in terms of floor space, microalgae and labour (Nghia, 2004; Ruscoe et al., 2004). On the contrary, rotifers used in the present study produced according to the procedures described by Lind (2014) were of high daily productivity and low production cost. Furthermore, extending the period of rotifer inclusion in the feeding regime could save the usage of Artemia (Quy et al., 2018). Therefore, extending rotifers inclusion mixed with Artemia until Z5 is possible to reduce cost production for mud crab hatchery.

Probiotics may rapidly alter the intestinal microbiota of the larvae. Gatesoupe (1999) showed that the intestinal microbiota of early larval stages was easily altered by the invasion of the microorganisms from water and food, even when their digestive tract was not fully developed and feeding had not yet commenced. In the present study, a mixture of Bacillus spp. was inoculated in live food at the beginning of the experiment; therefore, any harmful bacteria that could invade the cultured species through the food chain (Van Stappen, 1996, p.114) may have been reduced or eliminated. Enriched live food can also become a vector for bringing desirable microbes into the digestive system of the host (Lavilla-Pitogo et al., 2002), thereby potentially improving the properties of the indigenous microflora of the larvae as well as interfering with the development of harmful bacteria. For example, when the probiotic Bacillus spp. was used, Vibrio numbers were reduced and no luminous Vibrio responsible for losses in shrimp hatcheries existed (Moriarty, 1998; 1999). Similarly, Rengpipat et al. (1998) and Far et al. (2009) have reported that B. subtilis proliferated and replaced Vibrio spp. in the digestive tract of shrimp (P. monodon) treated with probiotics that increased in survival and growth of the shrimp. In agreement with these results, our study showed that the survival and metamorphosis rates of the larvae fed both enriched rotifers and Artemia with probiotics were higher than those fed a diet without enrichment. The reduction in the number of probiotic bacteria (Dan and Hamasaki, 2015) or low concentrations of probiotics in the diet (Tseng et al., 2009) induced individual differences among the replicated dietary treatments in any feeding trial. This may explain the fact that in the current study, enrichment of only one type of live feed could not significantly improve survival and rate of metamorphosis in crab larvae.

A study by Ruscoe et al. (2004) on $S$. serrata, as well as our earlier study (Quy et al., 2018) on $S$. parasamosain, showed that feeding a mixture of unenriched rotifers and Artemia until Z4 and Z5 stages obtained similar megalopa survival. On the contrary, in the present study feeding a mixture of rotifers and Artemia, irrespective of enrichment, until Z5, rather than Z4, improved megalopa survival, metamorphosis rates and growth. It is apparent that enrichment can be considered as a factor contributing to these differences. However, there were no significant interactive effects between enrichment/non-enrichment with probiotics and extension of rotifers inclusion on mud crab larval survival and metamorphosis rates, probably because the beneficial effect of the two factors studied was more of an additive affect rather than a synergistic affect.

\section{Conclusion}

In conclusion, inclusion of enriched rotifers mixed with enriched Artemia until the stage Z5 improved survival, metamorphosis rate and growth of megalopa. Further, the enrichment of both rotifers and Artemia as a live feed is crucial to achieve beneficial outcomes in crab hatcheries. However, these results needs to be validated under commercial farming operations, wherein other natural and/or anthropogenic factors interplay. However, current study can be used as a baseline data on the use of appropriate feeding regimes to improve the survival of mud crab larvae. There is also a need to compare the bio economics between the use of exclusive formulated feed and the feeding regime used in the current study.

\section{Acknowledgement}

The research was sponsored by the Curtin International Postgraduate Research Scholarships (CIPRS) and the Ministry of Education and Training (MoET) of Vietnam Awards. The authors would like to thank Mr Kha Tich $\mathrm{Vu}$ and Mrs Ong Kim Diep for supplying crab broodstocks, Mr. Vo Hong Hai and Mr. Vo Chi Thanh for supporting all hatchery facilities.

\section{Author's Contributions}

Quy Moc Ong: Participated in built up, designed, carried out, analysed data and drafted manuscript.

Ravi Fotedar: Contributed to check all the work as well as correct the manuscript.

ThyThi Truong Ho: Contributed carrying out experiment and analysing samples (counted bacteria concentration...).

\section{References}

Ambas, I., A. Suriawan and R. Fotedar, 2013. Immunological responses of customised probioticsfed marron, Cherax tenuimanus, (Smith 1912) when challenged with Vibrio mimicus. Fish Shellfish Immunol., 35: 262-270.

DOI: $10.1016 /$ j.fsi.2013.04.026 
Ambas, I., 2015. Physiological responses of customized probiotic fed marron, Cherax cainii (Austin, 2002). Doctoral dissertation, Curtin University.

Balcázar, J.L. and T. Rojas-Luna, 2007. Inhibitory activity of probiotic Bacillus subtilis UTM 126 against Vibrio species confers protection against Vibriosis in juvenile shrimp (Litopenaeus vannamei). Curr. Microbiol., 55: 409-412.

DOI: $10.1007 / \mathrm{S} 00284-007-9000-0$

Baylon, J.C., 2009. Appropriate food type, feeding schedule and Artemia density for the zoea larvae of the mud crab, Scylla tranquebarica (Crustacea: Decapoda: Portunidae). Aquaculture, 288: 190-195. DOI: $10.1016 /$ j.aquaculture.2008.11.028

Baylon, J.C., M.E.A. Bravo and N.C. Maningo, 2004. Ingestion of Brachionus plicatilis and Artemia salina nauplii by mud crab Scylla serrata larvae. Aquaculture Res., 35: 62-70. DOI: $10.1111 / \mathrm{j} .1365-2109.2004 .00987 . \mathrm{x}$

Baylon, J.C. and A.N. Failaman, 1999. Larval Rearing of the Mud Crab Scylla serrata in the Philippines. In: Mud Crab Aquaculture and Biology, Keenan, C.P. and A. Blackshaw (Eds.), ACIAR, Canberra, Australia, pp: 141-146.

Brick, R.W., 1974. Effects of water quality, antibiotics, phytoplankton and food on survival and development of larvae of Scylla serrata (Crustacea: Portunidae). Aquaculture, 3: 231-244. DOI: 10.1016/0044-8486(74)90074-X

Dan, S. and K. Hamasaki, 2015. Evaluation of the effects of probiotics in controlling bacterial necrosis symptoms in larvae of the mud crab Scylla serrata during mass seed production. Aquaculture Int., 23: 277-296.

DOI: $10.1007 / \mathrm{S} 10499-014-9815-1$

Dan, S., T. Kaneko, S. Takeshima, M. Ashidate and K. Hamasaki, 2013. Variations in larval morphology and their relationships to survival during mass seed production by the swimming crab, Portunus trituberculatus (Brachyura, Portunidae).

Aquaculture, 414-415: 109-118.

DOI: 10.1016/j.aquaculture.2013.07.029

Dan, S., M. Oshiro, M. Ashidate and K. Hamasaki, 2016. Starvation of Artemia in larval rearing water affects post-larval survival and morphology of the swimming crab, Portunus trituberculatus (Brachyura, Portunidae). Aquaculture, 452: 407-415. DOI: 10.1016/j.aquaculture.2015.06.004

Davis, J.A., 2003. Development of hatchery techniques for the mud crab Scylla serrata (Forskal) in South Africa. Doctoral Dissertation.

Decamp, O., D.J.W. Moriarty and P. Lavens, 2008. Probiotics for shrimp larviculture: Review of field data from Asia and Latin America. Aquaculture Res., 39: 334-338. DOI: 10.1111/j.1365-2109.2007.01664.x
Dong, H.B., Y.Q. Su, Y. Mao, X.X. You and S.X. Ding et al., 2014. Dietary supplementation with Bacillus can improve the growth and survival of the kuruma shrimp Marsupenaeus japonicus in high-temperature environments. Aquaculture Int., 22: 607-617. DOI: 10.1007/S10499-013-9688-8

Faleiro, F. and L. Narciso, 2009. Brachionus vs Artemia duel: Optimizing first feeding of Upogebia pusilla (Decapoda: Thalassinidea) larvae. Aquaculture, 295: 205-208. DOI: 10.1016/j.aquaculture.2009.07.008

Far, H.Z., C.R.B. Saad, H.M. Daud, S.A. Harmin and S. Shakibazadeh, 2009. Effect of Bacillus subtilis on the growth and survival rate of shrimp (Litopenaeus vannamei). African J. Biotechnol., 8: 3369-3376.

Farzanfar, A., 2006. The use of probiotics in shrimp aquaculture. Pathogens Dis., 48: 149-158. DOI: $10.1111 /$ j.1574-695X.2006.00116.x

Fu, L.L., Y. Wang, Z.C. Wu and W.F. Li, 2011. In vivo assessment for oral delivery of Bacillus subtilis harboring a viral protein (VP28) against white spot syndrome virus in Litopenaeus vannamei. Aquaculture, 322-323: 33-38.

DOI: $10.1016 /$ j.aquaculture.2011.09.036

Gatesoupe, F.J., 1999. The use of probiotics in aquaculture. Aquaculture, 180: 147-165. DOI: $10.1016 / \mathrm{S} 0044-8486(99) 00187-8$

Genodepa, J., P.C. Southgate and C. Zeng, 2004. Diet particle size preference and optimal ration for mud crab, Scylla serrata, larvae fed microbound diets. Aquaculture, 230: 493-505.

DOI: 10.1016/j.aquaculture.2003.09.009

Guo, J.J., K.F. Liu, S.H. Cheng, C.I. Chang and J.J. Lay et al., 2009. Selection of probiotic bacteria for use in shrimp larviculture. Aquaculture Res., 40: 609-618. DOI: $10.1111 /$ j.1365-2109.2008.02140.x

Gupta, A., G. Verma and P. Gupta, 2016. Growth performance, feed utilization, digestive enzyme activity, innate immunity and protection against Vibrio harveyi of freshwater prawn, Macrobrachium rosenbergii fed diets supplemented with Bacillus coagulans. Aquaculture Int., 24: 1379-1392.

DOI: $10.1007 / \mathrm{s} 10499-016-9996-\mathrm{x}$

Hamasaki, K., Y. Obata, S. Dan and S. Kitada, 2011. A review of seed production and stock enhancement for commercially important portunid crabs in Japan. Aquaculture Int., 19: 217-235. DOI: $10.1007 /$ s10499-010-9387-7

Hamasaki, K., M.A. Suprayudi and T. Takeuchi, 2002. Mass mortality during metamorphosis to megalops in the seed production of mud crab Scylla serrata (Crustacea, Decapoda, Portunidae). Fisheries Sci., 68: 1226-1232.

Harvey, E.A. and C.E. Epifanio, 1997. Prey selection by larvae of the common mud crab Panopeus herbstii Milne-Edwards. J. Exp. Marine Biol. Ecol., 217: 79-91. DOI: 10.1016/S0022-0981(97)00045-2 
Heasman, M.P. and D.R. Fielder, 1983. Laboratory spawning and mass rearing of the mangrove crab, Scylla serrata (Forskal), from first zoea to first crab stage. Aquaculture, 34: 303-316.

DOI: $10.1016 / 0044-8486(83) 90210-7$

Holme, M.H., P.C. Southgate and C. Zeng, 2007. Assessment of dietary lecithin and cholesterol requirements of mud crab, Scylla serrata, megalopa using semi-purified microbound diets. Aquaculture Nutrit., 13: 413-423.

DOI: $10.1111 / \mathrm{j} .1365-2095.2007 .00492 . x$

Jamali, H., A. Imani, D. Abdollahi, R. Roozbehfar and A. Isari, 2015. Use of probiotic Bacillus spp. in rotifer (Brachionus plicatilis) and Artemia (Artemia urmiana) enrichment: Effects on growth and survival of Pacific white shrimp, Litopenaeus vannamei, larvae. Probiot. Antimicrobial Proteins, 7: 118-125. DOI: $10.1007 / \mathrm{s} 12602-015-9189-3$

Keenan, C.P., 1999. Aquaculture of the Mud Crab, Genus Scylla-Past, Present and Future. In: Mud Crab Aquaculture and Biology, Keenan, C.P. and A. Blackshaw, ACIAR, Canberra, Australia, pp: 9-13.

Kumar, N.R., R.P. Raman, S.B. Jadhao, R.K. Brahmchari and K. Kumar et al., 2013. Effect of dietary supplementation of Bacillus licheniformis on gut microbiota, growth and immune response in giant freshwater prawn, Macrobrachium rosenbergii (de Man, 1879). Aquaculture Int., 21: 387-403. DOI: 10.1007/s10499-012-9567-8

Lakshmi, B., B. Viswanath and D.V.R. Sai Gopal, 2013. Probiotics as antiviral agents in shrimp aquaculture. J. Pathogens. DOI: 10.1155/2013/424123

Lavilla-Pitogo, C.R., D.D. Catedral, S.A.G. Pedrajas and L.D. De la Peña, 2002. Selection of probiotics for shrimp and crab hatcheries. Proceedings of the SEAFDEC-OIE Seminar-Workshop on Disease Control in Fish and Shrimp Aquaculture in Southeast Asia-Diagnosis and Husbandry Techniques, Dec. 4-6, Iloilo City, Philippines, pp: 136-150.

Le Vay, L., V.N. Ut and D.A. Jones, 2001. Seasonal abundance and recruitment in an estuarine population of mud crabs, Scylla paramamosain, in the Mekong Delta, Vietnam. Hydrobiologia, 449: 231-239. DOI: 10.1023/A:1017511002066

Lind, R.D., 2014. Effects of selected commercial diets and yeast substitution on the growth and associated microbiota of rotifer (Brachionusplicatilis). MSc Thesis.

Lindner, B., 2005. Impacts of mud crab hatchery technology in Vietnam (68pp.). Australian Centre for International Agricultural Research.

Liu, K.F., C.S. Chiu, Y.L. Shiu, W. Cheng and C.H. Liu, 2010. Effects of the probiotic, Bacillus subtilis E20, on the survival, development, stress tolerance and immune status of white shrimp, Litopenaeus vannamei larvae. Fish Shellfish Immunol., 28: 837-844.

DOI: $10.1016 /$ j.fsi.2010.01.012
Luis-Villaseñor, I.E., M.E. Macías-Rodríguez, B. Gómez-Gil, F. Ascencio-Valle and Á.I. CampaCórdova, 2011. Beneficial effects of four Bacillus strains on the larval cultivation of Litopenaeus vannamei. Aquaculture, 321: 136-144.

DOI: $10.1016 /$ j.aquaculture.2011.08.036

Mann, D., T. Asakawa and M. Pizzutto, 1999. Development of a Hatchery System for Larvae of the Mud Crab Scylla serrata at the Bribie Island Aquaculture Research Centre. In: Mud Crab Aquaculture and Biology, Keenan, C.P. and A. Blackshaw (Eds.), ACIAR, Canberra, Australia, pp: 153-158.

Marichamy, R., 1996. Mudcrab culture and hatchery. CMFRI Bull. Artificial Reefs Seafarm. Technol., 48: 103-107.

Moriarty, D.J.W., 1998. Control of luminous Vibrio species in penaeid aquaculture ponds. Aquaculture, 164: 351-358. DOI: 10.1016/S0044-8486(98)00199-9

Moriarty, D.J.W., 1999. Disease control in shrimp aquaculture with probiotic bacteria. Proceedings of the 8th International Symposium on Microbial Ecology, (SME' 99), Atlantic Canada Society for Microbial Ecology, Halifax, Canada, pp: 237-243.

NavinChandran, M., P. Iyapparaj, S. Moovendhan, R. Ramasubburayan and S. Prakash et al., 2014. Influence of probiotic bacterium Bacillus cereus isolated from the gut of wild shrimp Penaeus monodon in turn as a potent growth promoter and immune enhancer in $P$. monodon. Fish Shellfish Immunol., 36: 38-45. DOI: $10.1016 /$ j.fsi.2013.10.004

Nghia, T.T., 2004. Optimization of mud crab (Scylla paramamosain) larviculture in Vietnam. Doctoral Dissertation.

https://biblio.ugent.be/publication/2067929

Nghia, T.T., M. Wille, T.C. Binh, H.P. Thanh and N.V. Danh et al., 2007. Improved techniques for rearing mud crab Scylla paramamosain (Estampador 1949) larvae. Aquaculture Res., 38: 1539-1553. DOI: $10.1111 /$ j.1365-2109.2007.01814.x

Nimrat, S., S. Suksawat, T. Boonthai and V. Vuthiphandchai, 2012. Potential Bacillus probiotics enhance bacterial numbers, water quality and growth during early development of white shrimp (Litopenaeus vannamei). Vet. Microbiol., 159: 443-450. DOI: 10.1016/j.vetmic.2012.04.029

Nogami, K., K. Hamasaki, M. Maeda and K. Hirayama, 1997. Biocontrol method in aquaculture for rearing the swimming crab larvae Portunus trituberculatus. Hydrobiologia, 358: 291-295.

DOI: $10.1023 / \mathrm{a}: 1003149306511$

Noorbaiduri, S. and M. Ikhwanuddin, 2015. Artificial crablets production of orange mud crab, Scylla olivacea (Herbst, 1796) through in vitro fertilization technique. J. Fisheries Aquatic Sci., 10: 102-110. DOI: 10.3923/jfas.2015.102.110 
Pandiyan, P., D. Balaraman, R. Thirunavukkarasu, E.G.J. George and K. Subaramaniyan et al., 2013. Probiotics in aquaculture. Drug Invent. Today, 5: 55-59. DOI: 10.1016/j.dit.2013.03.003

Pestana, D. and A. Ostrensky, 1995. Occurrence of an alternative pathway in the larval development of the crab Chasmagnathus granulata Dana, 1851 under laboratory conditions. Hydrobiologia, 306: 33-40.

Quinitio, E.T., F.D. Parado-Estepa and V. Alava, 1999. Development of Hatchery Techniques for the Mud Crab Scylla serrata (Forskal): Comparison of Feeding Schemes. In: Mud Crab Aquaculture and Biology, Keenan, C.P. and A. Blackshaw (Eds.), ACIAR, Canberra, Australia, pp: 125-130.

Quy, O.M., R. Fotedar and H.T.T. Thy, 2018. Extension of Rotifer (Brachionus Plicatilis) inclusions in the larval diets of mud crab, Scylla paramamosain (Estampodor, 1949): Effects on survival, growth, metamorphosis and development time. Modern Applied Sci., 12: 65-74.

DOI: 10.5539/mas.v12n1p65

Redzuari, A., M. Azra, A. Abol-Munafi, Z. Aizam and Y. Hii et al., 2012. Effects of feeding regimes on survival, development and growth of blue swimming crab, Portunus pelagicus (Linnaeus, 1758) larvae. World Applied Sci. J., 18: 472-478.

Rengpipat, S., W. Phianphak, S. Piyatiratitivorakul and P. Menasveta, 1998. Effects of a probiotic bacterium on black tiger shrimp Penaeus monodon survival and growth. Aquaculture 167: 301-313. DOI: 10.1016/S0044-8486(98)00305-6

Rengpipat, S., S. Rukpratanporn, S. Piyatiratitivorakul and P. Menasaveta, 2000. Immunity enhancement in black tiger shrimp (Penaeus monodon) by a probiont bacterium (Bacillus S11). Aquaculture, 191: 271-288. DOI: 10.1016/S0044-8486(00)00440-3

Ruscoe, I.M., G.R. Williams and C.C. Shelley, 2004. Limiting the use of rotifers to the first zoeal stage in mud crab (Scylla serrata Forskål) larval rearing. Aquaculture, 231: 517-527.

DOI: $10.1016 / \mathrm{j}$.aquaculture.2003.11.021

Soundarapandian, P. and S. Sankar, 2008. Effect of probiotic on the survival and production of black tiger shrimp Penaeus monodon (Fabricius). Int. J. Zool. Res., 4: 35-41.

Suprayudi, M.A., T. Takeuchi and K. Hamasaki, 2004. Essential fatty acids for larval mud crab Scylla serrata: Implications of lack of the ability to bioconvert $\mathrm{C} 18$ unsaturated fatty acids to highly unsaturated fatty acids. Aquaculture, 231: 403-416. DOI: $10.1016 / \mathrm{S} 0044-8486(03) 00542-8$
Suprayudi, M.A., T. Takeuchi, K. Hamasaki and J. Hirokawa, 2002. Effect of Artemia feeding schedule and density on the survival and development of larval mud crab Scylla serrata. Fisheries Sci., 68: 1295-1303.

Talib, A., K.K. Onn, M.A. Chowdury, W.M.W. Din and K. Yahya, 2017. The beneficial effects of multispecies Bacillus as probiotics in enhancing culture performance for mud crab Scylla paramamosain larval culture. Aquaculture Int., 25: 849-866.

Tomasiewicz, D.M., D.K. Hotchkiss, G.W. Reinbold, R.B. Read and P.A. Hartman, 1980. The most suitable number of colonies on plates for counting. J. Food Protect., 43: 282-286.

Tseng, D.Y., P.L. Ho, S.Y. Huang, S.C. Cheng and Y.L. Shiu et al., 2009. Enhancement of immunity and disease resistance in the white shrimp, Litopenaeus vannamei, by the probiotic, Bacillus subtilis E20. Fish Shellfish Immunol., 26: 339-344. DOI: $10.1016 /$ j.fsi.2008.12.003

Uddin, S.A., M.A. Kader, M. Sikder, M.A. Hakim and M.M. Alam et al., 2013. Study of probiotics on the seed production of black tiger shrimp Penaeus monodon. Croat. J. Fisheries, 71: 124-130. https://hrcak.srce.hr/108851

Van Stappen, G., 1996. Use of cysts. In Manual on the production and use of live food for aquaculture. FAO.

Vinoj, G., B. Vaseeharan, B. DavidJayaseelan, P. Rajakumaran and C. Ravi, 2013. Inhibitory effects of Bacillus licheniformis (DAB1) and Pseudomonas aeruginosa (DAP1) against Vibrio parahaemolyticus isolated from Fenneropenaeus indicus. Aquaculture Int., 21: 1121-1135.

DOI: $10.1007 / \mathrm{s} 10499-012-9617-2$

Wang, Y.B., 2007. Effect of probiotics on growth performance and digestive enzyme activity of the shrimp Penaeus vannamei. Aquaculture, 269: 259-264. DOI: 10.1016/j.aquaculture.2007.05.035

Wu, H.J., L.B. Sun, C.B. Li, Z.Z. Li and Z. Zhang et al., 2014. Enhancement of the immune response and protection against Vibrio parahaemolyticusby indigenous probiotic Bacillus strains in mud crab (Scylla paramamosain). Fish Shellfish Immunol., 41: 156-162. DOI: 10.1016/j.fsi.2014.08.027

Yi, S.K., S.G. Lee and J.M. Lee, 2009. Preliminary study of seed production of the micronesian mud crab Scylla serrata (Crustacea: Portunidae) in Korea. Ocean Polar Res., 31: 257-264. DOI: 10.4217/OPR.2009.31.3.257

Yu, M.C., Z.J. Li, H.Z. Lin, G.L. Wen and S. Ma, 2008. Effects of dietary Bacillus and medicinal herbs on the growth, digestive enzyme activity and serum biochemical parameters of the shrimp Litopenaeus vannamei. Aquaculture Int., 16: 471-480.

DOI: $10.1007 / \mathrm{s} 10499-007-9159-1$ 
Zar, J.H., 2010. Biostatistical Analysis. 5th Edn., Prentice Hall, USA, pp: 670.

Zeng, C. and S. Li, 1999. Effects of Density and Different Combinations of Diets on Survival, Development, Dry Weight and Chemical Composition of Larvae of the Mud Crab Scylla paramamosain. In: Mud Crab Aquaculture and Biology, Keenan, C.P. and A. Blackshaw (Eds.), ACIAR, Canberra, Australia, pp: 159-166.

Zeng, C., S. Li and H. Zeng, 2004. Occurrence of additional Zoea-VI larvae in the mud crab, Scylla paramamosain (Estampador), reared in the laboratory. Hydrobiologia, 529: 49-58.

DOI: $10.1007 / \mathrm{s} 10750-004-4946-4$
Zhou, X.X., Y.B. Wang and W.F. Li, 2009. Effect of probiotic on larvae shrimp (Penaeus vannamei) based on water quality, survival rate and digestive enzyme activities. Aquaculture, 287: 349-353. DOI: $10.1016 / \mathrm{j}$.aquaculture.2008.10.046

Ziaei-Nejad, S., M.H. Rezaei, G.A. Takami, D.L. Lovett and A.R. Mirvaghefi et al., 2006. The effect of Bacillus spp. bacteria used as probiotics on digestive enzyme activity, survival and growth in the Indian white shrimp Fenneropenaeus indicus. Aquaculture, 252: 516-524.

DOI: $10.1016 / \mathrm{j}$.aquaculture.2005.07.021 